\title{
Central and peripheral administration of kisspeptin activates gonadotropin but not somatotropin secretion in prepubertal gilts
}

\author{
Clay A Lents, Neely L Heidorn, C Richard Barb ${ }^{1}$ and J Joe Ford ${ }^{2}$ \\ Department of Animal and Dairy Science, College of Agricultural and Environmental Sciences, 316 Edgar L Rhodes \\ Center for Animal and Dairy Science, The University of Georgia, 425 River Road, Athens, Georgia 30602-2771, USA, \\ ${ }^{1}$ Richard B Russell Agricultural Research Center, USDA-ARS, Athens, Georgia 30604-5667, USA and ${ }^{2}$ US Meat \\ Animal Research Center, USDA-ARS, Clay Center, Nebraska 68933, USA
}

Correspondence should be addressed to C A Lents; Email: clents@uga.edu

\begin{abstract}
It is well established that kisspeptin signaling is necessary for the onset of puberty in laboratory animals. However, the role that kisspeptin may have in regulating puberty in large domestic animals is unknown. We tested the hypothesis that either central or peripheral infusion of kisspeptin would stimulate gonadotropin and $\mathrm{GH}$ secretion in prepubertal gilts. In experiment 1 , prepubertal gilts were fitted with i.c.v. cannula and indwelling jugular catheters. Animals were randomly assigned to receive 0, 10, or $100 \mu \mathrm{g}$ kisspeptin in saline. In experiment 2, prepubertal gilts, fitted with indwelling jugular catheters, randomly received $0,1,2.5$, or 5 mg kisspeptin in saline intravenously. Serial blood samples were collected every $15 \mathrm{~min}$ for $3 \mathrm{~h}$ before and $5 \mathrm{~h}$ after infusions, and serum concentrations of LH, FSH, and GH were determined. Mean concentrations of $\mathrm{LH}$ and FSH remained at basal levels for control animals but were increased $(P<0.001)$ for animals receiving i.c.v. infusion of kisspeptin. Area under the LH and FSH curves following i.c.v. infusion of kisspeptin increased $(P<0.001)$ in a dose-dependent manner. Concentrations of $\mathrm{GH}$ were unaffected by i.c.v. treatment. Peripheral administration of kisspeptin increased $(P<0.05)$ serum concentrations of LH but not FSH or GH. Thus, kisspeptin can activate gonadotropic but not somatotropic hormone secretion in prepubertal gilts. The present data support the concept that kisspeptin plays a role in the mechanism involved in initiating puberty in swine.
\end{abstract}

Reproduction (2008) 135 879-887

\section{Introduction}

Gonadotropin-releasing hormone $(\mathrm{GnRH})$ is secreted from hypothalamic neurons and is transported through the hypophyseal portal veins to the anterior pituitary gland where it stimulates synthesis and secretion of luteinizing hormone and follicle-stimulating hormone ( $\mathrm{LH}$ and $\mathrm{FSH}$; Schally et al. 1971). These pituitary gonadotropins are essential for normal gonadal development and function (Brinkley 1981, Desjardins 1981, Clarke et al. 1983, Gharib et al. 1990). In mammals, the components of the hypothalamic-pituitary-gonadal (HPG) axis are functional prior to the normal onset of puberty (Lutz et al. 1984, Urbanski \& Ojeda 1987), which is thought to be brought about by central and peripheral changes that lead to increased activity of the GnRH pulse generator (Pelletier et al. 1981, Foster et al. 1985, Plant et al. 1989). However, the mechanisms within the brain that regulate the proper temporal release of GnRH from hypothalamic neurons to initiate puberty remain largely unknown.

In general, increased excitatory signals and reduced inhibitory signals to the GnRH neuronal network prompt the onset of puberty (Ojeda \& Urbanski 1994). With regard to the former, kisspeptins have been implicated as potent stimulators of the gonadotropic axis (Gottsch et al. 2004, Dhillo et al. 2005). Structurally related peptides, kisspeptins, are products of the KISS1 gene (Kotani et al. 2001, Ohtaki et al. 2001). Synthesized as a preprohormone, it is cleaved to liberate a 54 amino acid peptide that can be proteolytically processed (Takino et al. 2003) to shorter variants; all of which share the same amidated $\mathrm{C}$ terminus and retain full biological activity (Kotani et al. 2001, Ohtaki et al. 2001). Kisspeptin, acting through its cognate G-protein coupled receptor GPR54/ KISS1R (Kotani et al. 2001), is thought to be an important determinant in the onset of puberty (Seminara \& Kaiser 2005). Indeed, Gpr54/Kiss1r knockout mice failed to initiate puberty (Funes et al. 2003, Seminara et al. 2003) and naturally occurring mutations in GPR54/KISS1R result in idiopathic hypogonadotropic hypogonadism in humans (de Roux et al. 2003, Seminara et al. 2003, Semple et al. 2005). Expression of the KISS1 and GPR54/ KISS1R genes is both hormonally and developmentally regulated in the rodent (Navarro et al. 2004a, 2004b). Kisspeptin stimulates LH secretion (Matsui et al. 2004, 
Thompson et al. 2004, Navarro et al. 2005b) in a GnRHdependent manner (Gottsch et al. 2004, Shahab et al. 2005, Arreguin- Arevalo et al. 2007). It has been demonstrated that kisspeptin acts directly on $\mathrm{GnRH}$ neurons to stimulate $\mathrm{GnRH}$ and gonadoroptin secretion (Thompson et al. 2004, Irwig et al. 2005, Messager et al. 2005). This has culminated in the establishment of a role for kisspeptin in the initiation of puberty in the rodent and primate (Shahab et al. 2005, Castellano et al. 2006). Data are available with regard to the effects of kisspeptin on $\mathrm{LH}$ secretion in the adult ewe (Messager et al. 2005, Arreguin-Arevalo et al. 2007, Caraty et al. 2007). However, the possible role of kisspeptin in mediating the onset of puberty in large domestic species, in particular the pig, has yet to be determined.

In the present study, we hypothesize that kisspeptin is an important regulator of gonadotropin secretion in the pig. To test this hypothesis, we administered kisspeptin either centrally or peripherally to prepubertal gilts and measured changes in gonadotropin secretion. Because the occurrence of puberty in the pig is directed by mechanisms in which the HPG axis regulates both gonadal function and growth (Barb et al. 1999), we tested the hypothesis that kisspeptin would modulate growth hormone $(\mathrm{GH})$ secretion in the prepubertal gilt.

\section{Results}

\section{Experiment 1}

A treatment-time interaction $(P<0.001)$ was detected for serum concentrations of $\mathrm{LH}$. Prior to the i.c.v. infusion, serum concentrations of $\mathrm{LH}$ were similar for all animals $(0.25 \pm 0.03 \mathrm{ng} / \mathrm{ml})$. Following i.c.v. treatment, LH concentrations remained at basal levels for the control animals but were increased $(P<0.001)$ for animals receiving either 10 or $100 \mu \mathrm{g}$ kisspeptin (Figs 1 and 2). Mean concentration, peak concentration, and area under the curve (AUC) of serum $\mathrm{LH}$ were greater $(P<0.001)$ in period 2, following i.c.v. infusion, for kisspeptin-treated animals compared with saline-treated controls (Fig. 2). Mean concentration and AUC of serum LH in period 2 were greater $(P<0.01)$ for animals treated with the $100 \mu \mathrm{g}$ dose of kisspeptin compared with the $10 \mu \mathrm{g}$ dose (Fig. 2), but peak concentrations of serum LH in period 2 were similar (Fig. 2). All animals responded to a single i.v. bolus infusion of $\mathrm{GnRH}$ in period 3 with elevated serum LH (Fig. 1). Mean concentration and peak concentration of serum $\mathrm{LH}$ in period 3 were greater $(P<0.05)$ for control animals compared with kisspeptintreated animals (Fig. 2). Animals treated with the $10 \mu \mathrm{g}$ dose of kisspeptin had decreased $(P<0.05)$ AUC
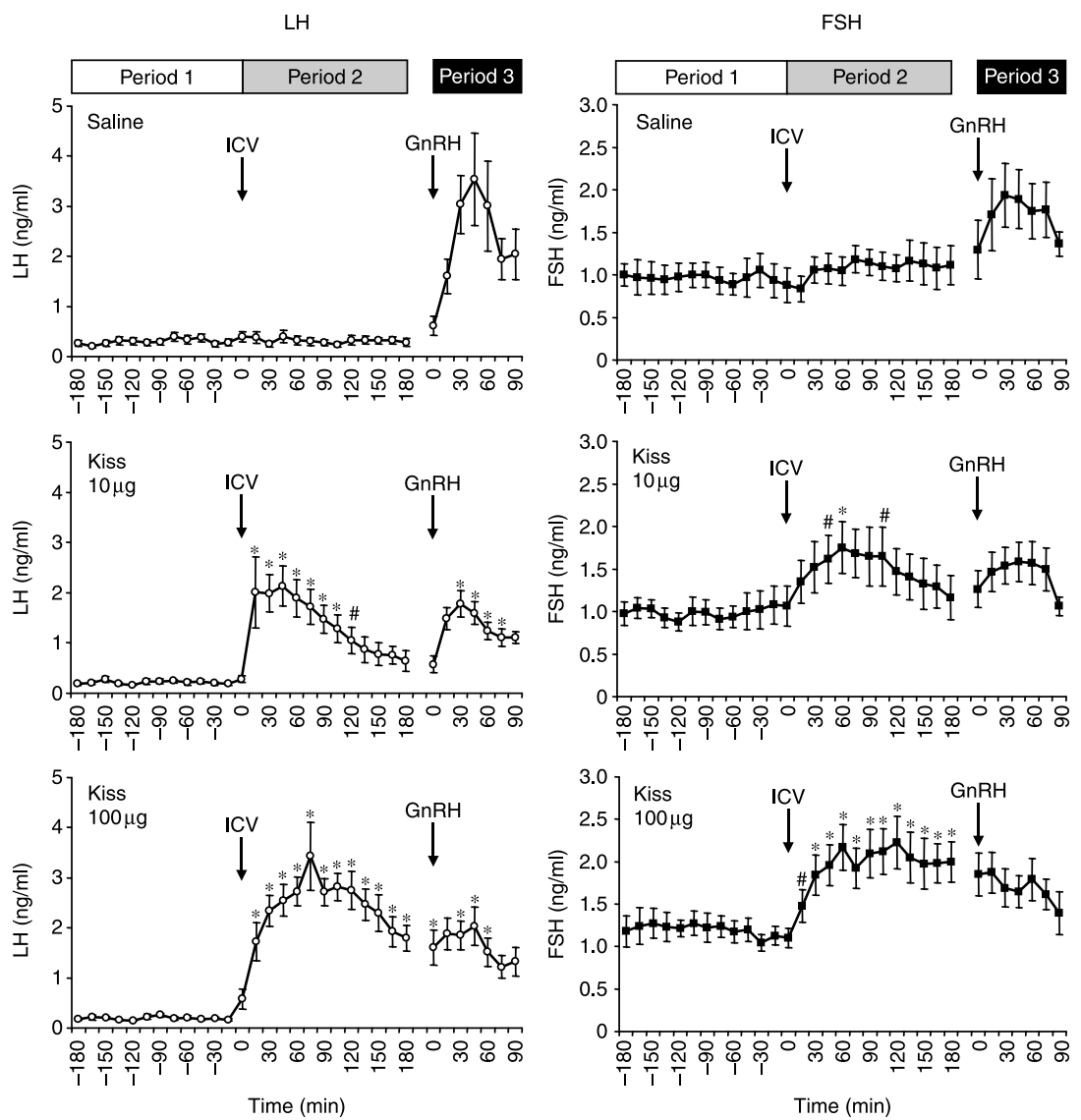

Figure 1 Serum concentrations of $\mathrm{LH}$ and $\mathrm{FSH}$ (means \pm S.E.M.) for prepubertal gilts receiving i.c.v. infusion of saline or either 10 or $100 \mu \mathrm{g}$ kisspeptin (Kiss). Period 1 is the $3 \mathrm{~h}$ prior to i.c.v. treatment; period 2 is the $3 \mathrm{~h}$ after i.c.v. treatment; period 3 is the $90 \mathrm{~min}$ following an i.v. injection of $100 \mu \mathrm{g} \mathrm{GnRH}$. A treatment-time interaction was detected for $\mathrm{LH}(P<0.001)$ and $\mathrm{FSH}$ $(P<0.001)$. *Times at which effects of treatment were different from saline-treated control animals $(P<0.05)$. "Times at which effects of treatment tended to be different from saline-treated control animals $(P<0.10)$. 

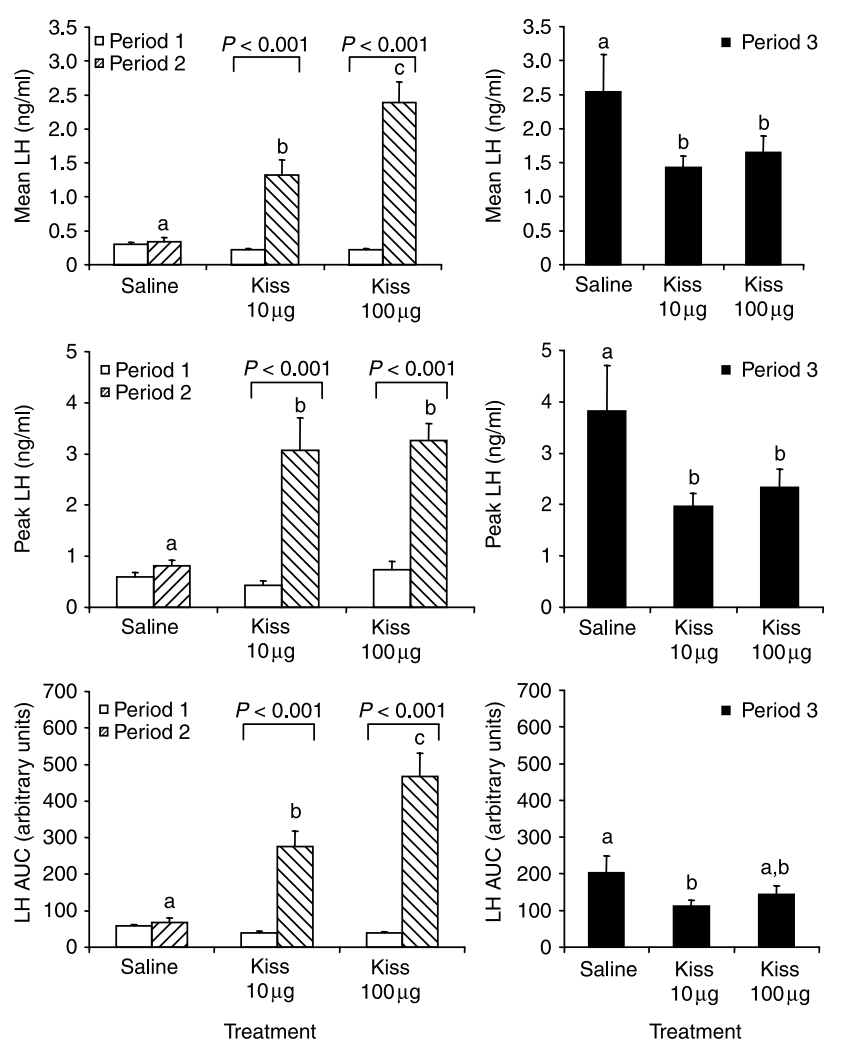

Figure 2 Mean $\mathrm{LH}$, peak $\mathrm{LH}$, and area under the curve (AUC) of serum $\mathrm{LH}$ for prepubertal gilts receiving i.c.v. infusion of saline or either 10 or $100 \mu \mathrm{g}$ kisspeptin (Kiss). Data in period 1 are from the $3 \mathrm{~h}$ prior to i.c.v. treatment; data in period 2 are from the $3 \mathrm{~h}$ after i.c.v. treatment; and data in period 3 are from the $90 \mathrm{~min}$ following an i.v. infusion of $100 \mu \mathrm{g}$ $\mathrm{GnRH}$. Data are presented as mean \pm S.E.M. ${ }^{\mathrm{a}, \mathrm{b}}$ Means within a period differ between treatments $(P<0.05)$.

following $\mathrm{GnRH}$ when compared with control animals treated with GnRH (Fig. 2). Area under the LH curve following GnRH was similar for control animals and those treated with the $100 \mu \mathrm{g}$ dose of kisspeptin (Fig. 2), since serum concentrations of LH in the kisspeptintreated animals were still above baseline at the beginning of period 3 (Fig. 1).

Similar to $\mathrm{LH}$, there was a treatment-time interaction $(P<0.001)$ for the effect of i.c.v. kisspeptin on FSH secretion (Fig. 1). Mean concentration, peak concentration, and AUC of serum FSH were increased $(P<0.001)$ in period 2 for kisspeptin-treated animals in a dose-dependent manner when compared with control animals (Fig. 3). Serum FSH concentrations were increased $(P<0.05)$ in control animals following $\mathrm{GnRH}$ treatment in period 3 (Fig. 1). Serum concentrations of FSH had not returned to baseline levels in the kisspeptintreated animals at the beginning of period 3 (Fig. 1), thus there was no difference in the parameters of $\mathrm{FSH}$ secretion between control and kisspeptin-treated animals following GnRH infusion (Fig. 3).

An expected variation in secretory patterns of $\mathrm{GH}$ between animals was observed; however, serum
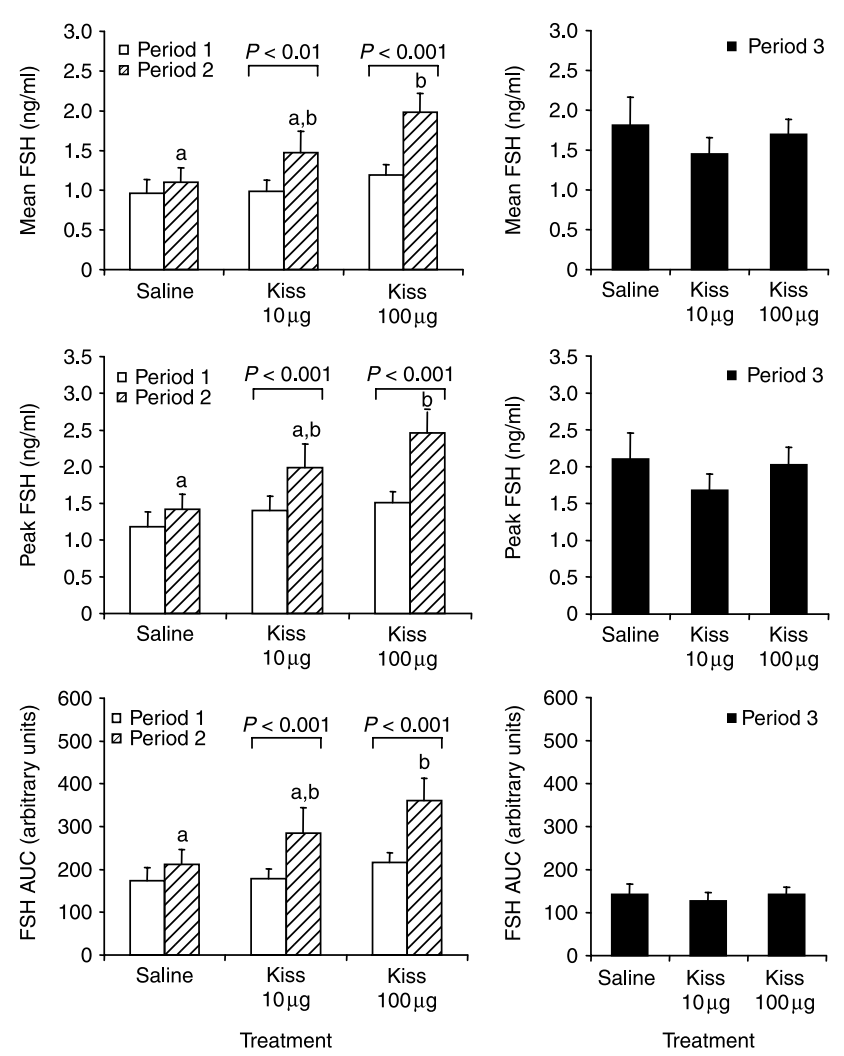

Figure 3 Mean FSH, peak FSH, and area under the curve (AUC) of serum FSH for prepubertal gilts receiving i.c.v. infusion of saline or either 10 or $100 \mu \mathrm{g}$ kisspeptin (Kiss). Data in period 1 are from the $3 \mathrm{~h}$ prior to i.c.v. treatment; data in period 2 are from the $3 \mathrm{~h}$ after i.c.v. treatment; and data in period 3 are from the $90 \mathrm{~min}$ following an i.v. infusion of $100 \mu \mathrm{g} \mathrm{GnRH}$. Data are presented as mean \pm s.E.M. ${ }^{\mathrm{a}, \mathrm{b}}$ Means within a period differ between treatments $(P<0.05)$.

concentrations of $\mathrm{GH}$ were not affected by i.c.v. treatment (Fig. 4). Mean concentrations of $\mathrm{GH}$ in serum following i.c.v. infusion were $4.15 \pm 1.9,2.33 \pm 0.5$, and $2.96 \pm 1.1 \mathrm{ng} / \mathrm{ml}$ for controls, Kiss $10 \mu \mathrm{g}$, and Kiss $100 \mu \mathrm{g}$ treated animals respectively.

\section{Experiment 2}

There was a treatment-time interaction $(P<0.001)$ for serum concentrations of $\mathrm{LH}$. Serum $\mathrm{LH}$ concentrations increased following i.v. infusion in all kisspeptin-treated animals (Fig. 5). Compared with period 1, mean concentration, peak concentration, and AUC of serum $\mathrm{LH}$ of control animals were unchanged in period 2 but were greater $(P<0.05)$ for all kisspeptin-treated animals (Fig. 7). Mean LH for animals treated with $5 \mathrm{mg}$ kisspeptin tended $(P<0.1)$ to be greater than for animals treated with $1 \mathrm{mg}$ kisspeptin (Fig. 7). Area under the LH curve increased $(P<0.05)$ in a linear fashion with increasing dose of kisspeptin (Fig. 7), which resulted from more sustained release of LH following the higher doses (Fig. 5). 

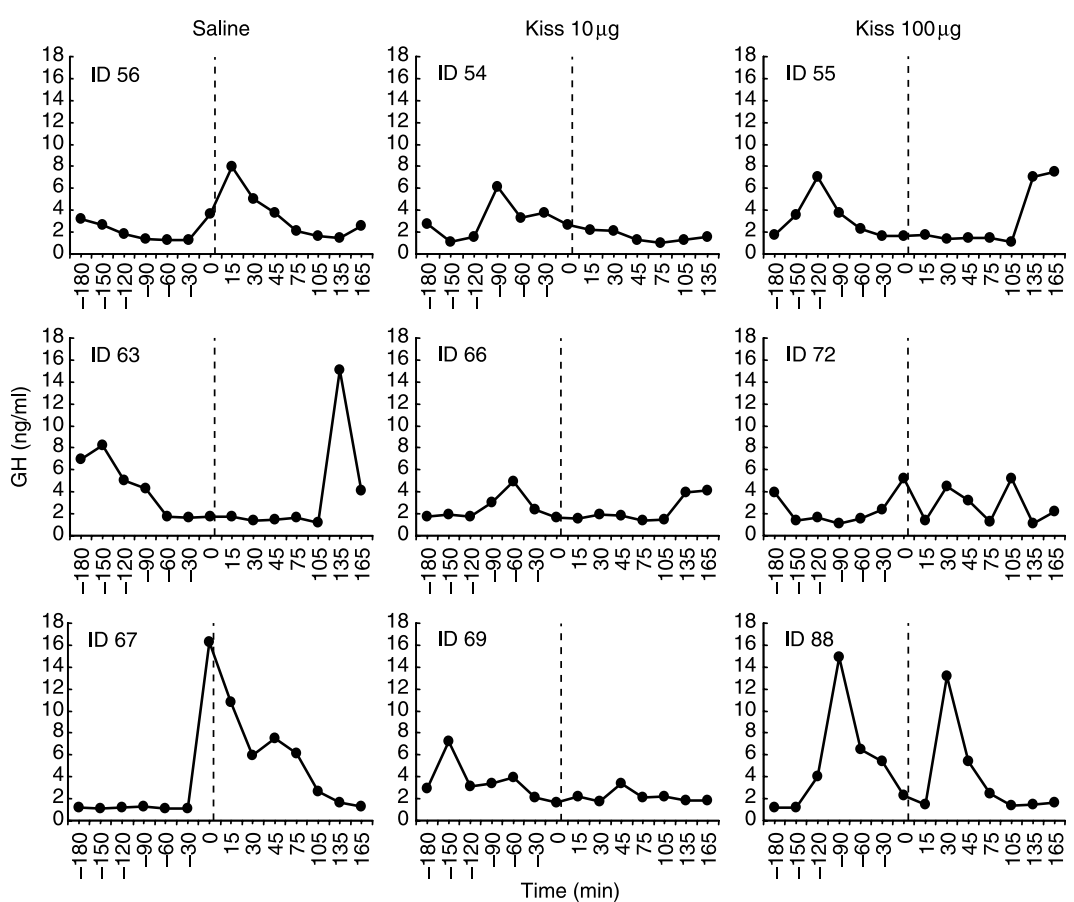

\begin{abstract}
Figure 4 Serum GH concentrations for prepubertal gilts receiving i.c.v. infusion of saline or either 10 or $100 \mu \mathrm{g}$ kisspeptin (Kiss). Data of three representative animals from each treatment are shown. The dashed vertical line indicates the time at which i.c.v. treatments were administered. There was no treatment-time interaction detected.
\end{abstract}

Intravenous infusion of kisspeptin at the highest dose tended $(P=0.08)$ to increase serum concentrations of FSH at $45-90$ min after treatment (Fig. 6). There was neither a treatment nor treatment-period interaction on parameters of FSH secretion (Fig. 7). However, the overall mean in period 2 was greater $(P<0.05)$ for peak FSH $(2.29 \pm 0.18$ vs $2.56 \pm 0.18 \mathrm{ng} / \mathrm{ml}$ for periods 1 and 2 respectively) and AUC of FSH (343 \pm 33 vs $395 \pm 33 \mathrm{ng} / \mathrm{ml}$ for periods 1 and 2 respectively) than in period 1. Concentrations of $\mathrm{GH}$ in serum were similar for all animals and were unchanged by i.v. infusion of 1, 2.5, or $5 \mathrm{mg}$ kisspeptin (Table 1).

\section{Discussion}

We report here for the first time that central infusion of kisspeptin to prepubertal gilts rapidly induces $\mathrm{LH}$ secretion. This strongly supports the concept that the role kisspeptin has in regulating the onset of puberty in the rodent (Navarro et al. 2004a, 2004b, Castellano et al. 2006) and primate (Plant et al. 2006) may be conserved in the domestic pig, which is an important biomedical model (Tumbleson 1986, Lunney 2007). The AUC, which reflects the integrated pattern of $\mathrm{LH}$ secretion, was increased by kisspeptin in a dose-dependent manner. The $10 \mu \mathrm{g}$ dose $(7.5 \mathrm{nmol})$ of kisspeptin resulted
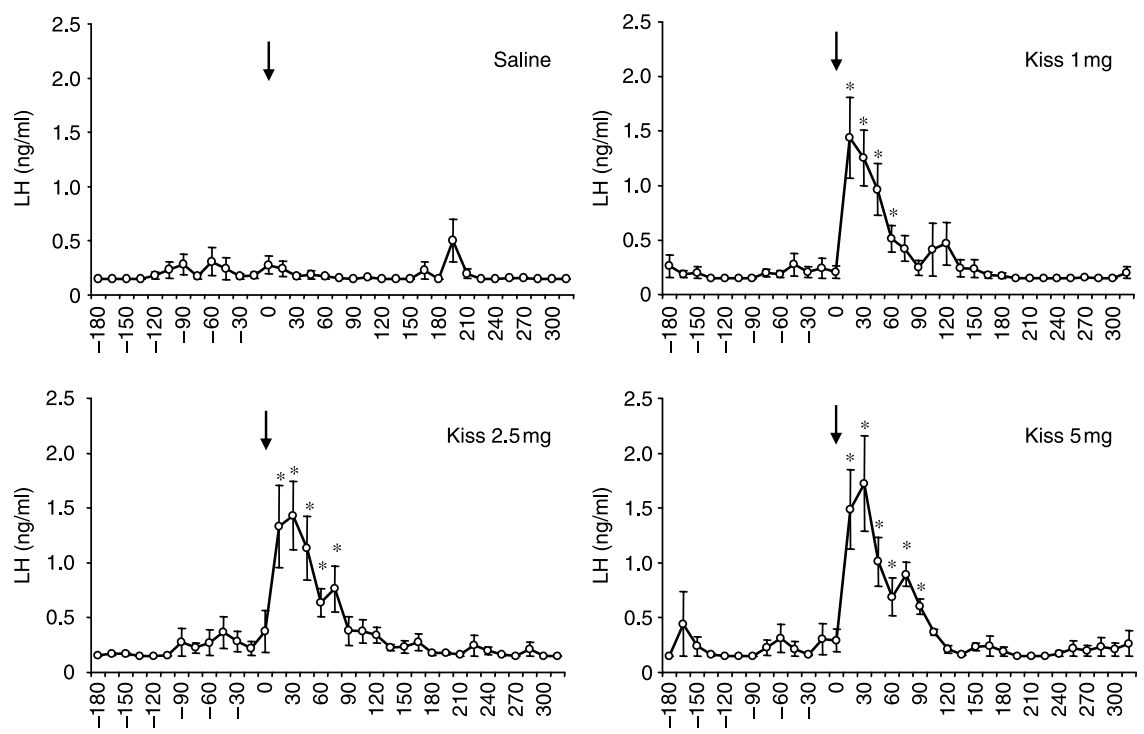

Figure 5 Serum LH concentrations (mean \pm S.E.M.) for prepubertal gilts receiving i.v. infusions of saline or either 1, 2.5, or $5 \mathrm{mg}$ kisspeptin (Kiss). A treatment-time interaction was detected $(P<0.01)$. ${ }^{*}$ Times at which effects of treatment were different from salinetreated control animals $(P<0.05)$. 

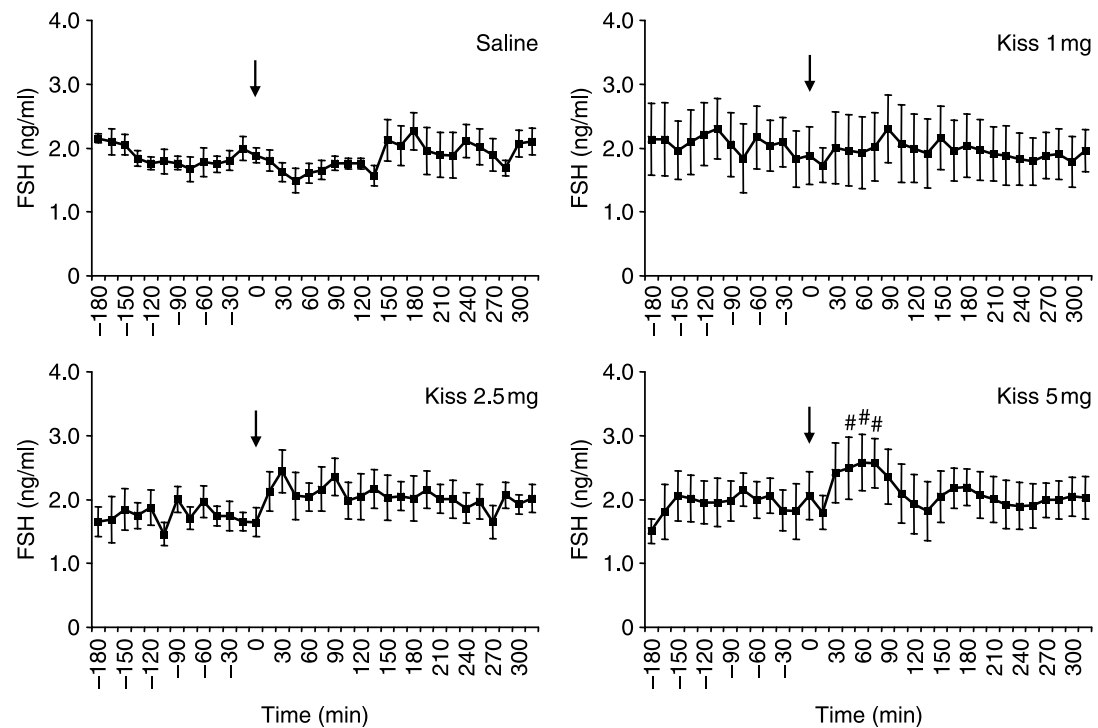

Figure 6 Serum FSH concentrations (mean \pm s.E.M.) for prepubertal gilts receiving i.v. infusions of saline or either 1, 2.5, or $5 \mathrm{mg}$ kisspeptin (Kiss). A tendency for a treatment-time interaction was detected $(P=0.08)$. "Times at which effects of treatment tended to be different from salinetreated control animals $(P<0.10)$. in a rapid pulse of $\mathrm{LH}$ that gradually declined over the next $3 \mathrm{~h}$, whereas the pulse of $\mathrm{LH}$ induced by $100 \mu \mathrm{g}$ $(75 \mathrm{nmol})$ kisspeptin persisted throughout the sampling period. Presumably, this reflects the kisspeptin-induced pattern of $\mathrm{GnRH}$ secretion. Kisspeptin has been shown to stimulate the in vitro release of $\mathrm{GnRH}$ from hypothalamic explants of rats (Thompson et al. 2004), and central infusion of ovariectomized ewes with $50 \mathrm{nmol}$ kisspeptin over a 4-h period caused the sustained secretion of $\mathrm{GnRH}$ into the cerebrospinal fluid
$\mathrm{LH}$
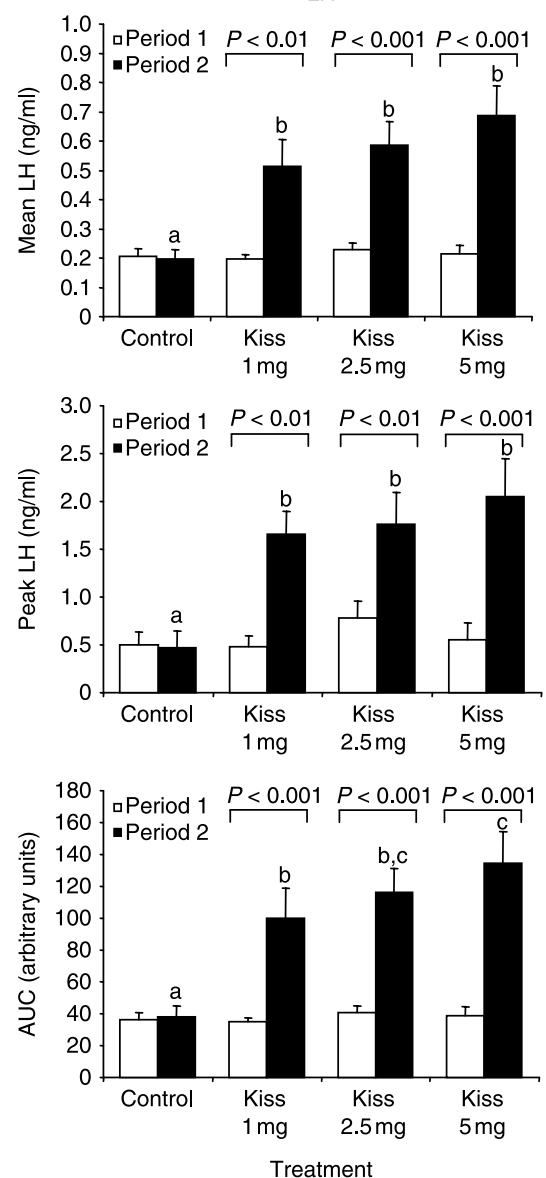

www.reproduction-online.org
FSH
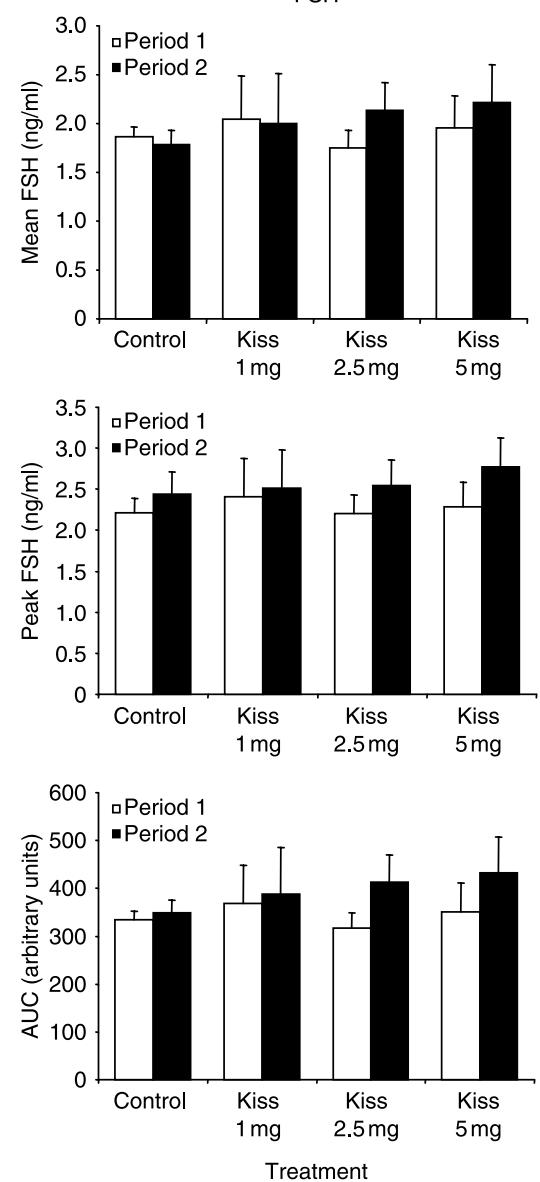

Figure 7 Mean concentration, peak concentration and area under the curve (AUC) of serum $\mathrm{LH}$ and FSH for prepubertal gilts receiving i.v. infusion of saline or either 1, 2.5, or 5 mg kisspeptin (Kiss). Data in period 1 are from of the $3 \mathrm{~h}$ prior to treatment and data in period 2 are from the $3 \mathrm{~h}$ after treatment. Data are presented as mean \pm S.E.M. $a, b, c$ Means within a period differ between treatments $(P<0.05)$. 
Table 1 Effect of i.v. administration of kisspeptin (Kiss) on serum concentrations of growth hormone (GH; ng/ml) in prepubertal gilts.

\begin{tabular}{|c|c|c|c|c|c|c|c|c|}
\hline \multirow[b]{2}{*}{ Period $^{\mathrm{a}}$} & \multicolumn{4}{|c|}{ Treatment } & \multirow[b]{2}{*}{ S.E.M. ${ }^{b}$} & \multicolumn{3}{|c|}{$P$ value } \\
\hline & Control & Kiss $1 \mathrm{mg}$ & Kiss $2.5 \mathrm{mg}$ & Kiss $5 \mathrm{mg}$ & & Treatment & Period & Treatment-period \\
\hline 1 & 3.11 & 3.17 & 2.92 & 3.90 & 0.39 & 0.16 & 0.56 & 0.70 \\
\hline 2 & 2.56 & 3.23 & 2.74 & 4.03 & 0.47 & & & \\
\hline
\end{tabular}

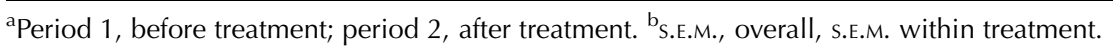

concomitantly with elevated serum concentrations of $\mathrm{LH}$ (Messager et al. 2005). We cannot preclude, however, that the pattern of $\mathrm{LH}$ secretion observed here might be caused by alterations in $\mathrm{GnRH}$ pulse frequency or amplitude. Whether or not kisspeptin regulates the $\mathrm{GnRH}$ pulse generator is not presently known. Regardless, pituitary function was intact in these animals as indicated by the increased LH secretion in control pigs following an i.v. infusion of $\mathrm{GnRH}$ in period 3 . The GnRH-induced release of $\mathrm{LH}$ in animals that had received i.c.v. infusions of kisspeptin was reduced when compared with that of the control animals that had received i.c.v. infusion of saline. In view of the prolonged stimulation of $\mathrm{LH}$ release following kisspeptin treatment, this reduced response to $\mathrm{GnRH}$ likely reflects a reduction in the releasable pool of $\mathrm{LH}$.

In order to determine whether peripheral administration of kisspeptin could induce LH secretion in prepubertal pigs, we administered an i.v. bolus of kisspeptin at three different doses. All three doses tested were able to elevate secretion of $\mathrm{LH}$ in these animals. This is substantiated by reports in rodents and monkeys which demonstrate kisspeptin stimulates LH secretion when given either centrally or peripherally (Matsui et al. 2004, Navarro et al. 2005b, Shahab et al. 2005). At the time our study was conducted, it was reported that i.v. administration of $<3 \mathrm{mg}$ kisspeptin to ovariectomized ewes resulted in somewhat variable $\mathrm{LH}$ release (Arreguin-Arevalo et al. 2007). Since the completion of our study, it has now been shown that i.v. administration of kisspeptin at doses of $<1 \mathrm{mg}$ can reliably elicit $\mathrm{LH}$ secretion, at least in the ovariectomized estradiol-treated ewe (Caraty et al. 2007). In the present study, the magnitude of LH release was similar for all doses of kisspeptin but the duration was longer with increasing dose. Whether or not i.v. infusion of kisspeptin at $<1 \mathrm{mg}$ can reliably induce LH secretion in the pig warrants further investigation.

Information regarding the effects of kisspeptin on FSH secretion is limited. We demonstrate that the central administration of kisspeptin to prepubertal gilts increased serum concentrations of FSH. This effect of kisspeptin on FSH secretion in the pig is in agreement with reports in rodents (Matsui et al. 2004, Thompson et al. 2004, Navarro et al. 2005a) and primates (Plant et al. 2006). The increase in FSH induced by kisspeptin showed more gradual onset and the magnitude was less than that of $\mathrm{LH}$. The ED50 of kisspeptin to release $\mathrm{FSH}$ has been estimated to be $\sim 100$ times higher than that for LH in rats (Navarro et al. 2005a). This may reflect the fact that FSH is not wholly under the control of GnRH (Kile \& Nett 1994, Phillips 2005). Despite a clear effect of i.c.v.-infused kisspeptin on FSH secretion, i.v. infusion only tended to alter FSH secretory patterns in prepubertal gilts infused with the highest dose of kisspeptin. This is similar to observations in the ovariectomized ewe (Arreguin-Arevalo et al. 2007). However, it was recently reported that doses of kisspeptin up to tenfold less than used in our experiment were able to stimulate FSH secretion in ovariectomized estradiol-treated ewes (Caraty et al. 2007). Differences in species and physiological status of the animals may account for differing results when kisspeptin is infused intravenously.

Concentrations of FSH in serum remained elevated at the end of the $3 \mathrm{~h}$ sampling period in the animals receiving i.c.v. infusion of $100 \mu \mathrm{g}$ kisspeptin, despite the fact that LH in those animals was declining. Interestingly, a similar observation has recently been reported in ovariectomized estradiol-treated ewes (Caraty et al. 2007). In the present experiment, we were unable to determine whether this is due to a true change in secretion, or to the longer half-life of FSH (Macdonald et al. 2007). In the pig, circulating concentrations of LH are reduced more rapidly than those of FSH after a bolus GnRH infusion (Wise et al. 1996). Nonetheless, the initial pattern of FSH secretion induced by i.c.v. infusion of kisspeptin is similar to that caused by i.v. infusion of $\mathrm{GnRH}$ in the control animals. This supports the concept that the primary mechanism of kisspeptin-induced FSH secretion is mediated through the $\mathrm{GnRH}$ neuronal network (Thompson et al. 2004, Irwig et al. 2005, Messager et al. 2005).

During preparation of this manuscript, it was reported that i.v. administration of kisspeptin stimulated $\mathrm{GH}$ secretion in prepubertal heifer calves (Kadokawa et al. 2008). Indeed, age-related changes in serum concentrations of $\mathrm{GH}$ occur in the pig but typically decline as the animal is approaching puberty (Machlin et al. 1968, Klindt \& Stone 1984, Dubreuil et al. 1987). We found no effect of either central or peripheral administration of kisspeptin on secretion of $\mathrm{GH}$ in the present study. Divergence with regard to kisspeptin's actions on $\mathrm{GH}$ secretion may be related to species differences. However, our experiment included a true control group, which may have allowed us to more 
accurately delineate the effect of kisspeptin on $\mathrm{GH}$ secretion in the pig. The inclusion of saline-treated controls clearly illustrate that, in our hands, kisspeptin does not modulate the secretion of $\mathrm{GH}$ in the prepubertal pig, and agrees with observations in monkeys (Plant personal communication).

In conclusion, here we report that kisspeptin can activate the gonadotropic axis in the prepubertal pig. The ability of kisspeptin to stimulate hormone secretion from the anterior pituitary gland of the pig seems to be specific for $\mathrm{LH}$ and FSH and did extend to $\mathrm{GH}$ in this study. We presently do not know whether other anterior pituitary hormones in the pig are affected by kisspeptin. Our data are consistent with the idea that kisspeptin's actions on gonadotropin secretion are mediated primarily through modulating secretion of $\mathrm{GnRH}$ and support the concept that kisspeptin plays an important role in regulating puberty.

\section{Materials and Methods}

All procedures involving animals were approved by the Institutional Animal Care and Use Committee of The University of Georgia. Prepubertal gilts (sow line C42, boar line 280; PIC, Franklin, KY, USA) weighing $67.6 \pm 7.2 \mathrm{~kg}$ (mean \pm s.D.) and 130-day age were used. Animals were born and reared at the Swine Research Center at The University of Georgia. During experiments, animals were moved to a Large Animal Research Unit, where they were kept in individual pens under controlled temperature $\left(22^{\circ} \mathrm{C}\right)$ and had access to feed and water ad libitum unless otherwise noted. The diet was formulated to meet National Research Council guidelines (NRC 1988) for growing swine. Kisspeptin consisted of the ten C-terminal amino acids of the murine peptide and was obtained from GenScript Corp. (Scotch Plains, NJ, USA). GnRH was obtained from Sigma or Merial Limited (Cystorelin; Iselin, NJ, USA).

\section{Experiment 1}

Animals $(n=14)$ were surgically fitted with a lateral i.c.v. cannula using a steriotaxic procedure described previously (Estienne et al. 1990, Barb et al. 1993). Placement of the i.c.v. cannula of each animal was verified by X-ray. At least 1 week after the placement of i.c.v. cannula, and $24 \mathrm{~h}$ prior to treatment, all animals were fitted with indwelling jugular catheters (Barb et al. 1982). Animals were randomly assigned to one of three groups. Control animals received $150 \mu \mathrm{l}$ PBS. The other groups received either 10 or $100 \mu \mathrm{g}$ kisspeptin in $150 \mu \mathrm{l}$ PBS. Doses of kisspeptin were based on our previous experience with i.c.v. administration of hormones to the pigs (Barb et al. 2004, Barb \& Barrett 2005). Serial blood samples were drawn every 15 min for $3 \mathrm{~h}$ before (period 1 ) and $3 \mathrm{~h}$ after (period 2) i.c.v. treatment, and for $90 \mathrm{~min}($ period 3) following an i.v. bolus infusion of $100 \mu \mathrm{g} \mathrm{GnRH}$. The time from the end of period 2 to the beginning of period 3 was $15-45 \mathrm{~min}$. The inclusion of the $\mathrm{GnRH}$ treatment was to verify that pituitary function was intact and that $\mathrm{LH}$ secretion could in fact be induced in these prepubertal gilts. One week later, the experiment was replicated with animals reassigned to treatment so that no animal received the same treatment a second time, resulting in eight pigs for the control treatment and ten pigs for each dose of kisspeptin. Gilts were killed and the ovaries were subjected to gross inspection to confirm the absence of luteal structures.

\section{Experiment 2}

Experiment 2 was conducted with six prepubertal gilts in each treatment group to determine the response to increasing doses of kisspeptin administered as a single bolus i.v. infusion. Animals were fitted with indwelling jugular catheters the day prior to the experiment. Animals received 1, 2.5, or $5 \mathrm{mg}$ kisspeptin in $3 \mathrm{ml}$ PBS or $3 \mathrm{ml}$ PBS alone for the control animals. Doses were chosen in part based on the reported effective dose in sheep (Arreguin-Arevalo et al. 2007). At $0730 \mathrm{~h}$, feeders were removed from pens and blood sampling started at $0800 \mathrm{~h}$. Serial blood samples were drawn every $15 \mathrm{~min}$ for $3 \mathrm{~h}$ before (period 1) and $5 \mathrm{~h}$ after (period 2) treatment. Feeders were returned to all pens after the last blood sample was drawn.

\section{Hormone analysis}

Blood was allowed to clot for $1 \mathrm{~h}$ at room temperature and then $4{ }^{\circ} \mathrm{C}$ overnight. Serum was separated by centrifugation and stored at $-20{ }^{\circ} \mathrm{C}$ for subsequent analysis of LH (Kesner et al. 1987) and FSH (Trout et al. 1992) by RIA. The reference standard for LH (AFP-10506A) and FSH (AFP-10640B) was provided by Dr A F Parlow, Scientific Director of the NIH, NIDDK, National Hormone and Peptide Program. Sensitivity of the assays was 0.15 and $0.2 \mathrm{ng} / \mathrm{ml}$ for $\mathrm{LH}$ and FSH respectively. Intra- and inter-assay coefficient of variation (CV) of LH assays were 7.9 and $9.8 \%$ respectively. Four pools of porcine serum with FSH concentrations that ranged from 1 to $3 \mathrm{ng} / \mathrm{ml}$ were included in each assay; these had intra-assay $\mathrm{CV}$ that ranged from 4 to $16 \%$. Serum concentrations of $\mathrm{GH}$ were determined using a porcine RIA kit (Millipore Corp., Billerica, MA, USA). Sensitivity of the assay was $1 \mathrm{ng} / \mathrm{ml}$ and intra- and inter-assay CV were 8.6 and $13.4 \%$ respectively.

\section{Statistical analysis}

To determine the effect of kisspeptin on serum concentrations of $\mathrm{LH}, \mathrm{FSH}$, and $\mathrm{GH}$, data were subjected to generalized least squares ANOVA with repeated measures using the MIXED procedure of SAS (1999). The model included replicate, treatment, time, and all first- and second-order interactions, with a compound symmetric function used to model the covariance structure for the repeated measures. If a significant $(P<0.05)$ treatment-time interaction was detected, the simple effects of treatment within a time were compared using the SLICE option of the LSMEANS statement of SAS. Mean concentration, peak concentration, and AUC of serum $\mathrm{LH}$ and $\mathrm{FSH}$ at fixed periods were subjected to generalized least squares ANOVA with repeated measures. In experiment 1, 
periods 1 and 2 were defined as the $3 \mathrm{~h}$ before and $3 \mathrm{~h}$ after i.c.v. treatment respectively. Period 3 was defined as the $90 \mathrm{~min}$ following i.v. infusion of $\mathrm{GnRH}$. In experiment 2, periods 1 and 2 were defined the same as in experiment 1 . The model included replicate, treatment, period, and all first- and secondorder interactions, with a compound symmetric function used to model the covariance structure for the repeated measures.

\section{Acknowledgements}

The authors wish to thank B Jackson, L Lee-Rutherford, C Rogers, G McKinney, A Kruger, and J Segerf for technical assistance as well as M Daniels for expert animal husbandry. The authors thank Drs A Nelson, J K Bertrand, and R Rekaya for their statistical consultation. The authors wish to acknowledge Dr A F Parlow, Scientific Director of the NIH, NIDDK, National Hormone and Peptide Program, for providing porcine $\mathrm{LH}$ and $\mathrm{FSH}$ for radioiodination and standard preparation as well as FSH antibody (AFP-C5288113Rb) for RIA. This research was supported by USDA funds and State funds allocated to the Georgia Agricultural Experiment Station and in part by a National Research Initiative Competitive Grant (no. 200535023-15949 and 2005-35203-16852) from the USDA Cooperative State Research, Education, and Extension Service. Mention of trade name, proprietary product, or specific equipment does not constitute a guarantee or warranty by the US Department of Agriculture or The University of Georgia and does not imply its approval to the exclusion of other products which may be suitable. The authors declare that there is no conflict of interest that would prejudice the impartiality of this scientific work.

\section{References}

Arreguin-Arevalo JA, Lents CA, Farmerie TA, Nett TM \& Clay CM 2007 KiSS-1 peptide induces release of $\mathrm{LH}$ by a direct effect on the hypothalamus of ovariectomized ewes. Animal Reproduction Science 101 265-275.

Barb CR \& Barrett JB 2005 Neuropeptide Y modulates growth hormone but not luteinizing hormone secretion from prepuberal gilt anterior pituitary cells in culture. Domestic Animal Endocrinology 29 548-555.

Barb CR, Kraeling RR, Rampacek GB, Fonda ES \& Kiser TE 1982 Inhibition of ovulation and LH secretion in the gilt after treatment with ACTH or hydrocortisone. Journal of Reproduction and Fertility 64 85-92.

Barb CR, Kraeling RR, Estienne MJ \& Rampacek GB 1993 Technique for cannulation of the lateral ventricle of the brain in swine. Kopf Carrier 35 $1-5$.

Barb CR, Kraeling RR, Rampacek GB \& Estienne MJ 1999 Current concepts of the onset of puberty in the gilt. 3rd Conference of the European Society for Domestic Animal Reproduction Supplement 6 82-88.

Barb CR, Barrett JB \& Kraeling RR 2004 Role of leptin in modulating the hypothalamic-pituitary axis and luteinizing hormone secretion in the prepuberal gilt. Domestic Animal Endocrinology 26 201-214.

Brinkley HJ 1981 Endocrine signaling and female reproduction. Biology of Reproduction 24 22-43.

Caraty A, Smith JT, Lomet D, Said SB, Morrissey A, Cognie J, Doughton B, Baril G, Briant C \& Clarke IJ 2007 Kisspeptin synchronizes preovulatory surges in cyclic ewes and causes ovulation in seasonally acyclic ewes. Endocrinology 148 5258-5267.

Castellano JM, Navarro VM, Fernandez-Fernandez R, Castano JP, Malagon MM, Aguilar E, Dieguez C, Magni P, Pinilla L \& TenaSempere M 2006 Ontogeny and mechanisms of action for the stimulatory effect of kisspeptin on gonadotropin-releasing hormone system of the rat. Molecular and Cellular Endocrinology 257-258 $75-83$.
Clarke IJ, Cummins JT \& de Kretser DM 1983 Pituitary gland function after disconnection from direct hypothalamic influences in the sheep. Neuroendocrinology 36 376-384.

Desjardins C 1981 Endocrine signaling and male reproduction. Biology of Reproduction 24 1-21.

Dhillo WS, Chaudhri OB, Patterson M, Thompson EL, Murphy KG, Badman MK, McGowan BM, Amber V, Patel S, Ghatei MA et al. 2005 Kisspeptin-54 stimulates the hypothalamic-pituitary-gonadal axis in human males. Journal of Clinical Endocrinology and Metabolism 90 6609-6615.

Dubreuil P, Pelletier G, Petitclerc D, Lapierre H, Couture Y, Brazeau P, Gaudreau P \& Morisset J 1987 Influence of age and sex on basal secretion of growth hormone $(\mathrm{GH})$ and on $\mathrm{GH}$-induced release by porcine $\mathrm{GH}$-releasing factor pGRF $\left(1-29 \mathrm{NH}_{2}\right)$ in growing pigs. Domestic Animal Endocrinology 4 299-307.

Estienne MJ, Kesner JS, Barb CR, Kraeling RR, Rampacek GB \& Estienne CE 1990 Gonadotropin and prolactin secretion following intraventricular administration of morphine in gilts. Proceedings of the Society for Experimental Biology and Medicine 193 92-97.

Foster DL, Yellon SM \& Olster DH 1985 Internal and external determinants of the timing of puberty in the female. Journal of Reproduction and Fertility 75 327-344.

Funes S, Hedrick JA, Vassileva G, Markowitz L, Abbondanzo S, Golovko A, Yang S, Monsma FJ \& Gustafson EL 2003 The KiSS-1 receptor GPR54 is essential for the development of the murine reproductive system. Biochemical and Biophysical Research Communications 312 1357-1363.

Gharib SD, Wierman ME, Shupnik MA \& Chin WW 1990 Molecular biology of the pituitary gonadotropins. Endocrine Reviews 11 177-199.

Gottsch ML, Cunningham MJ, Smith JT, Popa SM, Acohido BV, Crowley WF, Seminara S, Clifton DK \& Steiner RA 2004 A role for kisspeptins in the regulation of gonadotropin secretion in the mouse. Endocrinology 145 4073-4077.

Irwig MS, Fraley GS, Smith JT, Acohido BV, Popa SM, Cunningham MJ, Gottsch ML, Clifton DK \& Steiner RA 2005 Kisspeptin activation of gonadotropin releasing hormone neurons and regulation of KiSS-1 mRNA in the male rat. Neuroendocrinology 80 264-272.

Kadokawa H, Matsui M, Hayashi K, Matsunaga N, Kawashima C, Shimizu T \& Miyamoto A 2008 Peripheral administration of kisspeptin-10 increases plasma concentrations of $\mathrm{GH}$ as well as $\mathrm{LH}$ in prepubertal holstein heifers. Journal of Endocrinology 196 331-334.

Kesner JS, Kraeling RR, Rampacek GB \& Johnson B 1987 Absence of an estradiol-induced surge of luteinizing hormone in pigs receiving unvarying pulsatile gonadotropin-releasing hormone stimulation. Endocrinology 121 1862-1869.

Kile JP \& Nett TM 1994 Differential secretion of follicle-stimulating hormone and luteinizing hormone from ovine pituitary cells following activation of protein kinase $\mathrm{A}$, protein kinase $\mathrm{C}$, or increased intracellular calcium. Biology of Reproduction 50 49-54.

Klindt J \& Stone RT 1984 Porcine growth hormone and prolactin: concentrations in the fetus and secretory patterns in the growing pig. Growth 48 1-15.

Kotani M, Detheux M, Vandenbogaerde A, Communi D, Vanderwinden JM, Le Poul E, Brezillon S, Tyldesley R, Suarez-Huerta N, Vandeput F et al. 2001 The metastasis suppressor gene KiSS-1 encodes kisspeptins, the natural ligands of the orphan G protein-coupled receptor GPR54. Journal of Biological Chemistry 276 34631-34636.

Lunney JK 2007 Advances in swine biomedical model genomics. International Journal of Biological Sciences 3 179-184.

Lutz JB, Rampacek GB, Kraeling RR \& Pinkert CA 1984 Serum luteinizing hormone and estrogen profiles before puberty in the gilt. Journal of Animal Science 58 686-691.

Macdonald GJ, Wise TH, Sluss PM \& Ford JJ 2007 Breed differences in clearance of porcine FSH in hypophysectomized rats. Animal Reproduction Science 102 328-334.

Machlin LV, Horino M, Hertelendy F \& Kipnis DM 1968 Plasma growth hormone and insulin levels in the pig. Endocrinology 82 369-376.

Matsui H, Takatsu Y, Kumano S, Matsumoto H \& Ohtaki T 2004 Peripheral administration of metastin induces marked gonadotropin release and ovulation in the rat. Biochemical and Biophysical Research Communications 320 383-388. 
Messager S, Chatzidaki EE, Ma D, Hendrick AG, Zahn D, Dixon J, Thresher RR, Malinge I, Lomet D, Carlton MB et al. 2005 Kisspeptin directly stimulates gonadotropin-releasing hormone release via $G$ protein-coupled receptor 54. PNAS 102 1761-1766.

Navarro VM, Castellano JM, Fernandez-Fernandez R, Barreiro ML, Roa J, Sanchez-Criado JE, Aguilar E, Dieguez C, Pinilla L \& Tena-Sempere M 2004a Developmental and hormonally regulated messenger ribonucleic acid expression of KiSS-1 and its putative receptor, GPR54, in rat hypothalamus and potent luteinizing hormone-releasing activity of KiSS1 peptide. Endocrinology 145 4565-4574.

Navarro VM, Fernandez-Fernandez R, Castellano JM, Roa J, Mayen A, Barreiro ML, Gaytan F, Aguilar E, Pinilla L, Dieguez C et al. 2004b Advanced vaginal opening and precocious activation of the reproductive axis by KiSS-1 peptide, the endogenous ligand of GPR54. Journal of Physiology 561 379-386.

Navarro VM, Castellano JM, Fernandez-Fernandez R, Tovar S, Roa J, Mayen A, Barreiro ML, Casanueva FF, Aguilar E, Dieguez C et al. 2005a Effects of KiSS-1 peptide, the natural ligand of GPR54, on folliclestimulating hormone secretion in the rat. Endocrinology 146 1689-1697.

Navarro VM, Castellano JM, Fernandez-Fernandez R, Tovar S, Roa J, Mayen A, Nogueiras R, Vazquez MJ, Barreiro ML, Magni P et al. 2005b Characterization of the potent luteinizing hormone-releasing activity of KiSS-1 peptide, the natural ligand of GPR54. Endocrinology 146 156-163.

NRC 1988 Nutrient Requirements of Pigs, Washington, DC: National Academy Press.

Ohtaki T, Shintani Y, Honda S, Matsumoto H, Hori A, Kanehashi K, Terao Y, Kumano S, Takatsu Y, Masuda Y et al. 2001 Metastasis suppressor gene KiSS-1 encodes peptide ligand of a G-protein-coupled receptor. Nature 411 613-617.

Ojeda SR \& Urbanski HF 1994 In Puberty in the Rat, Eds E Knobil \& JD Neill. New York: Raven Press.

Pelletier J, Carrez-Camous S \& Thiery JC 1981 Basic neuroendocrine events before puberty in cattle, sheep and pigs. Journal of Reproduction and Fertility 30 91-102.

Phillips DJ 2005 Activins, inhibins and follistatins in the large domestic species. Domestic Animal Endocrinology 28 1-16.

Plant TM, Gay VL, Marshall GR \& Arslan M 1989 Puberty in monkeys is triggered by chemical stimulation of the hypothalamus. PNAS $\mathbf{8 6}$ 2506-2510.

Plant TM, Ramaswamy S \& Dipietro MJ 2006 Repetitive activation of hypothalamic G protein-coupled receptor 54 with intravenous pulses of kisspeptin in the juvenile monkey (Macaca mulatta) elicits a sustained train of gonadotropin-releasing hormone discharges. Endocrinology 147 1007-1013.

de Roux N, Genin E, Carel JC, Matsuda F, Chaussain JL \& Milgrom E 2003 Hypogonadotropic hypogonadism due to loss of function of the KiSS1derived peptide receptor GPR54. PNAS 100 10972-10976.
SAS 1999 SAS User's Guide (Resease 8.0), Cary, NC: Statistical Analysis Systems Institute, Inc.

Schally AV, Arimura A, Baba Y, Nair RM, Matsuo H, Redding TW \& Debeljuk L 1971 Isolation and properties of the FSH and LH-releasing hormone. Biochemical and Biophysical Research Communications 43 393-399.

Seminara SB \& Kaiser UB 2005 New gatekeepers of reproduction: GPR54 and its cognate ligand, KiSS-1. Endocrinology 146 1686-1688.

Seminara SB, Messager S, Chatzidaki EE, Thresher RR, Acierno JS Jr, Shagoury JK, Bo-Abbas Y, Kuohung W, Schwinof KM, Hendrick AG et al. 2003 The GPR54 gene as a regulator of puberty. New England Journal of Medicine 349 1614-1627.

Semple RK, Achermann JC, Ellery J, Farooqi IS, Karet FE, Stanhope RG, O'rahilly S \& Aparicio SA 2005 Two novel missense mutations in GPR54 in a patient with hypogonadotropic hypogonadism. Journal of Clinical Endocrinology and Metabolism 90 1849-1855.

Shahab M, Mastronardi C, Seminara SB, Crowley WF, Ojeda SR \& Plant TM 2005 Increased hypothalamic GPR54 signaling: a potential mechanism for initiation of puberty in primates. PNAS 102 2129-2134.

Takino T, Koshikawa N, Miyamori H, Tanaka M, Sasaki T, Okada Y, Seiki M \& Sato H 2003 Cleavage of metastasis suppressor gene product KiSS-1 protein/metastin by matrix metalloproteinases. Oncogene 22 4617-4626.

Thompson EL, Patterson M, Murphy KG, Smith KL, Dhillo WS, Todd JF, Ghatei MA \& Bloom SR 2004 Central and peripheral administration of kisspeptin-10 stimulates the hypothalamic-pituitary-gonadal axis. Journal of Neuroendocrinology 16 850-858.

Trout WE, Killen JH, Christenson RK, Schanbacher BD \& Ford JJ 1992 Effects of weaning on concentrations of inhibin in follicular fluid and plasma of sows. Journal of Reproduction and Fertility 94 107-114.

Tumbleson ME 1986 In Swine in Biomedial Research, Ed. ME Tumbleson. New York: Plenum Press.

Urbanski HF \& Ojeda SR 1987 Activation of luteinizing hormone-releasing hormone release advances the onset of female puberty. Neuroendocrinology 46 273-276.

Wise T, Lunstra DD \& Ford JJ 1996 Differential pituitary and gonadal function of Chinese Meishan and European white composite boars: effects of gonadotropin-releasing hormone stimulation, castration, and steroidal feedback. Biology of Reproduction 54 146-153.

Received 7 November 2007

First decision 4 December 2007

Revised manuscript received 25 January 2008

Accepted 26 February 2008 